\title{
Peroxyacetyl nitrate (PAN) concentrations in the Antarctic troposphere measured during the photochemical experiment at Neumayer (PEAN'99)
}

\author{
H.-W. Jacobi ${ }^{\mathrm{a}, *}$, R. Weller ${ }^{\mathrm{a}}$, A.E. Jones ${ }^{\mathrm{b}}$, P.S. Anderson ${ }^{\mathrm{b}}$, O. Schrems ${ }^{\mathrm{a}}$ \\ ${ }^{a}$ Alfred Wegener Institute for Polar and Marine Research, Am Handelshafen 12, 27570 Bremerhaven, Germany \\ british Antarctic Survey, Natural Environment Research Council, High Cross, Madingley Road, Cambridge CB3 OET, UK
}

Received 30 November 1999; received in revised form 15 March 2000; accepted 24 March 2000

\begin{abstract}
Because investigations of PAN at higher southern latitudes are very scarce, we measured surface PAN concentrations for the first time in Antarctica. During the Photochemical Experiment at Neumayer (PEAN'99) campaign mean surface PAN mixing ratios of $13 \pm 7 \mathrm{pptv}$ and maximum values of $48 \mathrm{pptv}$ were found. When these PAN mixing ratios were compared to the sum of $\mathrm{NO}_{x}$ and inorganic nitrate they were found to be equal or higher. Low ambient air temperatures and low PAN concentrations caused a slow homogeneous PAN decomposition rate of approximately $5 \times 10^{-2} \mathrm{pptv} \mathrm{h}^{-1}$. These slow decay rates were not sufficient to firmly establish the simultaneously observed $\mathrm{NO}_{x}$ concentrations. In addition, low concentration ratios of $\left[\mathrm{HNO}_{3}\right] /\left[\mathrm{NO}_{x}\right]$ imply that the photochemical production of $\mathrm{NO}_{x}$ within the snow pack can influence surface $\mathrm{NO}_{x}$ mixing ratios in Antarctica. Alternate measurements of PAN mixing ratios at two different heights above the snow surface were performed to derive fluxes between the lower troposphere and the underlying snow pack using calculated friction velocities. Most of the concentration differences were below the precision of the measurements. Therefore, only an upper limit for the PAN flux of $\pm 1 \times 10^{13}$ molecules $\mathrm{m}^{-2} \mathrm{~s}^{-1}$ without a predominant direction can be estimated. However, PAN fluxes below this limit can still influence both the transfer of nitrogen compounds between atmosphere and ice, and the PAN budget in higher southern latitudes. (C) 2000 Elsevier Science Ltd. All rights reserved.
\end{abstract}

Keywords: Peroxyacetyl nitrate; Antarctica; Nitrogen oxides; Nitrogen budget; Air-surface exchange

\section{Introduction}

Peroxyacetyl nitrate (PAN) is an important compound within the class of reactive nitrogen oxides in the atmosphere. While it is mainly produced during the oxidation of organic compounds in the presence of nitrogen oxides, its destruction is dominated by thermal decompositon. Therefore, many field and modelling studies (e.g. Kleindienst, 1994; Moxim et al., 1996; Jaffe et al., 1997;

\footnotetext{
* Corresponding author; Present address: Department of Hydrology and Water Resources, 1133 E. North Campus Dr., P.O. Box 210011, University of Arizona, Tucson, AZ 85721-0011, USA.

E-mail address: hwj@hwr.arizona.edu (H.-W. Jacobi).
}

Wang et al., 1998) have shown that high PAN concentrations not only occur in regions with strong sources of its precursors (e.g. highly polluted urban areas) but also at low temperatures in regions with no sources (e.g. Arctic, or middle and upper troposphere). Concurrent observations of PAN and the sum of reactive nitrogen $\left(\mathrm{NO}_{y}\right)$ have revealed that PAN can constitute up to $90 \%$ of the total $\mathrm{NO}_{y}$ budget at higher northern latitudes or higher altitudes (Bottenheim et al., 1986, 1993; Barrie et al., 1989; Bottenheim and Gallant, 1989; Muthuramu et al., 1994; Solberg et al., 1997; Sandholm et al., 1992; Singh et al., 1994, 1998; Bradshaw et al., 1998; Talbot et al., 1999). Despite lower PAN concentration at lower altitudes in remote marine areas, its decomposition has been found to be sufficient to maintain observed $\mathrm{NO}_{x}$ 
$\left(=\mathrm{NO}+\mathrm{NO}_{2}\right)$ mixing ratios (e.g. Heikes et al., 1996; Jacob et al., 1996; Schultz et al., 1999), thus demonstrating that PAN can act as a transport agent for $\mathrm{NO}_{x}$ from its continental sources to remote tropospheric regions. As a result, PAN influences the $\mathrm{NO}_{x}$ balance, which in turn critically controls photochemical production and destruction of ozone in many regions of the troposphere (e.g. Carroll and Thompson, 1995).

In addition to its role in tropospheric photochemistry, PAN is thought to be of great importance for the airsnow-transfer of nitrogen compounds in high northern latitudes. Because PAN constitutes a large fraction of the arctic $\mathrm{NO}_{y}$ budget, Munger et al. (1999) assume that it participates in the $\mathrm{NO}_{y}$ transfer and must be taken into account for the interpretation of nitrate concentrations in ice cores. Moreover, a recent investigation of $\mathrm{NO}_{y}$ gradients above the snowpack in Greenland indicate that $\mathrm{NO}_{y}$ fluxes can be of different size and direction compared to concurrently measured $\mathrm{HNO}_{3}$ fluxes (Dibb et al., 1998). Due to PAN's high abundance in Greenland, it may be suggested that PAN contributes to the observed $\mathrm{NO}_{y}$ fluxes.

Despite its great impact at higher latitudes, no direct observations of PAN mixing ratios in Antarctica have been reported in the literature. Therefore, measurements of PAN concentrations were part of the Antarctica field campaign Photochemical Experiment at Neumayer (PEAN'99) performed at the German research station in the second half of the austral summer 1999. Besides this first experimental investigation of PAN mixing ratios in Antarctica, a wide range of chemical and physical variables were measured during this program, including $\mathrm{NO}, \mathrm{NO}_{2}, \mathrm{HNO}_{3}$, and particulate nitrate $\left(\mathrm{p}-\mathrm{NO}_{3}^{-}\right)$. This suite of measurements provides a unique opportunity to study the partitioning of odd nitrogen compounds in the lower troposphere over Antarctica. We further investigated gradients of PAN concentrations in the lower $2.5 \mathrm{~m}$ above the snow surface to resolve fluxes of PAN between the atmosphere and the underlying snow pack.

\section{Methods and instrumentation}

Measurements of PAN, $\mathrm{NO}, \mathrm{NO}_{2}, \mathrm{HNO}_{3}$ and $\mathrm{p}-\mathrm{NO}_{3}^{-}$ concentrations were performed within the frame of the Photochemical Experiment at Neumayer 1999 (PEAN'99) campaign which was conducted between 25th January and 28th February 1999 at the German research station Neumayer $\left(70^{\circ} 39^{\prime} \mathrm{N}, 8^{\circ} 15^{\prime} \mathrm{W}\right)$. This station is located on the Ekström ice shelf, about $8 \mathrm{~km}$ from the Atka Bay. The analysers were installed in a specially equipped laboratory container located $1.5 \mathrm{~km}$ south of the main station near the permanent Air Chemistry Observatory. In this location prevailing wind directions are from east. Concentrations measured during wind directions from the north could be affected by contamination from emissions of the base. During the campaign this situation occurred only on 14 February between 20:30 and 22:30 UTC. These data were discarded from the original data sets which were then used for further analysis. Normally, air masses advected to Neumayer passed over the continent for two to three days, but originate generally from marine regions.

Three different inlet lines were used for collecting air samples for PAN measurements. For gradient measurements two inlet lines (each $9 \mathrm{~m}$ in length of $0.4 \mathrm{~cm}$ ID perfluoroalkoxy (PFA) tubing) were fixed at two vertical braces of a mast at 0.1 and $2.5 \mathrm{~m}$ height above the snow surface. At the beginning of the campaign the mast was erected approximately $5 \mathrm{~m}$ west of the container. Until the first gradient measurements the snow surface was completely renewed due to several days of strong snow drift. Inside the container both inlet lines were connected via a three-way Teflon valve with a manifold. The valve was switched every $10 \mathrm{~min}$ from the upper to the lower inlet line which were both flushed with a flow rate of about $71 \mathrm{~min}^{-1}$ leading to a residence time of the air samples in the tubes and the manifold of less than $3 \mathrm{~s}$. In addition, a third inlet line ( $10 \mathrm{~m}$ of $0.4 \mathrm{~cm}$ ID PFA) was fixed at a height of approximately $2.3 \mathrm{~m}$ and equipped with a spray deflector. This line was connected to the manifold during periods with strong snow drift. From the manifold air was sucked into the analyser using a second pump.

The method for the PAN measurements is based on electron capture gas chromatography with cryogenic pre-concentration technique (Schrimpf et al., 1995). Details of the commercial analyser (Meteorologie Consult $\mathrm{GmbH}$, Glashütten, Germany) were recently described (Jacobi et al., 1999). After enrichment for $7 \mathrm{~min}$ on a Peltier-cooled cryogenic sampling trap at $0^{\circ} \mathrm{C}$, desorption was maintained by quickly heating the pre-concentration loop. The gas mixture was transferred to the analytical column with nitrogen as carrier gas. The separation was performed within $10 \mathrm{~min}$ analytical cycles using pre- and main columns maintained at $12^{\circ} \mathrm{C}$. Only a selected fraction including PAN was passed from the pre-column onto the main column. The eluates of the main column were analysed by electron capture detection (ECD) at $60^{\circ} \mathrm{C}$. Calibration was based on photochemical synthesis of PAN using NO-premixtures in the presence of acetone and synthetic air (Warneck and Zerbach, 1992). A flow reactor equipped with a penray lamp (Meteorologie Consult GmbH, Glashütten, Germany) was used for the synthesis. The limit of detection (LOD) was derived from the noise of the output signal of the analyser when air produced by a clean air generator (PAG 003, Eco Physics GmbH, Munich, Germany) was analysed. A LOD of 5 pptv is obtained from two times the standard deviation of the noise. Multipoint calibrations were performed at the beginning and at the end of 
the campaign and showed good agreement resulting in an estimated overall precision of $\pm 15 \%$ or $\pm 3 \mathrm{ppt}$, whatever is higher.

NO was measured with a chemiluminescence detector (CLD 780 TR, Eco Physics GmbH, Munich, Germany) based on the conversion of ambient $\mathrm{NO}$ to excited $\mathrm{NO}_{2}^{*}$ in a flow reactor. A preceding reduction of $\mathrm{NO}_{2}$ to $\mathrm{NO}$ using a photolytic converter (PLC 760, Eco Physics $\mathrm{GmbH}$, Munich, Germany) allows the selective detection of $\mathrm{NO}_{2}$ in a separate measurement cycle. The conversion efficiency of the photolytic converter was determined every 5-7 days to be in the range of $63-66 \%$ throughout the campaign. The calculated accuracies of the NO and $\mathrm{NO}_{2}$ measurements were $\pm 2-3$ and $\pm 3-4$ pptv, respectively. LODs of 3 pptv for $\mathrm{NO}$ and 4 pptv for $\mathrm{NO}_{2}$ were calculated. Samples for $\mathrm{HNO}_{3}$ were collected in the Air Chemistry Observatory using a low volume threestage Teflon/nylon/nylon filter combination described by Jones et al. (1999). The air intake height for the filter samples was approximately $7 \mathrm{~m}$ above the snow level. Local contamination by anthropogenic sources was prevented by a wind and condensation particle-controlled sampling procedure (Wagenbach et al., 1988). The collected filters were extracted using MilliQ water, the Teflon filters having first been wetting with $<200 \mu$ isopropanol. The solution was then analysed with an ion chromatograph to determine the nitrate content. Regular blank determinations were used to estimate an overall error including the IC error and the error of the sample air volume. Errors of $21 \%$ for $\mathrm{HNO}_{3}$ and $9 \%$ for $\mathrm{p}-\mathrm{NO}_{3}^{-}$ were derived. The LOD calculated from twice the standard deviation of the blank values was found to be $1 \mathrm{pptv}$ for both compounds.

In addition, continuous measurements of meteorological quantities (temperature, wind speed, wind direction, relative humidity) were routinely performed at Neumayer Station. All parameters except the PAN gradients were averaged to 20-min means. Because $\mathrm{HNO}_{3}$ concentrations are averages for longer sample integration intervals the obtained values were used for all 20min intervals within the several filter sampling periods.

\section{Results and discussion}

\subsection{PAN time series}

Fig. 1 shows the observed PAN time series during PEAN'99. Ambient concentrations were measured between 1 and 28 February 1999. The mixing ratios were in the range from $<5$ pptv (LOD) to $48 \mathrm{pptv}$. The values exhibited a strong temporal variability without a distinct diurnal variation and an average of $13 \pm 7$ pptv for the entire campaign.

A comparison with PAN mixing ratios previously obtained in high northern latitudes (e.g. Bottenheim et al., 1994; Muthuramu et al., 1994; Beine et al., 1996; Jacobi et al., 1999) shows that the concentrations in the Antarctic



Fig. 1. Time series of PAN measured at Neumayer station during PEAN'99. 
obtained during this campaign were approximately one order of magnitude lower. This difference is probably due to the fact that the Arctic is surrounded by continents which are strong sources of PAN precursors (Roberts, 1990). Trajectory analysis of PAN measurements at $\mathrm{Ny}-$ Alesund, Svalbard, has demonstrated that air masses with origins over Europe or Asia were accompanied by higher PAN concentrations compared to air masses with marine or polar origins (Solberg et al., 1997; Jacobi et al., 1999). The larger distance from other continents makes the transport of PAN or its precursors to higher southern latitudes less effective. Therefore, several global modelling studies have demonstrated that surface PAN mixing ratios in Antarctica could be considerably lower than in the Arctic (e.g. Moxim et al., 1996; Jaffe et al., 1997; Wang et al., 1998). Moxim et al. (1996) and Wang et al. (1998) calculated mixing ratios below 10 pptv for Antarctica in January, while Jaffe et al. (1997) obtained concentrations between 10 and 30 pptv in April. The mean PAN concentration of 13 pptv observed during this study are in good agreement with the simulated results. However, they cannot explain our maximum values in the order of $40 \mathrm{pptv}$. These high concentrations can probably be explained by long-range transport of PAN-enriched air from lower latitudes or higher altitudes. Several airborne and ship-based field experiments have demonstrated that PAN mixing ratios are normally below $10 \mathrm{pptv}$ in the MBL of the Southern Hemisphere (Singh et al., 1986, 1996, 1998; Rudolph et al., 1987; Müller and Rudolph, 1992; Schultz et al., 1999). In contrast, recent investigations onboard RV Polarstern showed that over the South Atlantic mean PAN concentrations of 60 pptv north of $49^{\circ} \mathrm{S}$ can occur (Jacobi and Schrems, 1999). Müller and Rudolph (1992) also found mixing ratios up to $100 \mathrm{pptv}$ around $30^{\circ} \mathrm{S}$ in air masses influenced by continental emissions. In addition, high PAN concentrations up to 140 pptv were observed in the upper and middle troposphere of the southern hemisphere (Singh et al., 2000). For example, the global PAN distribution simulated by Moxim et al. (1996) shows concentrations in the range of 20-50 pptv at a height of $8 \mathrm{~km}$ at $60^{\circ} \mathrm{S}$. In order to investigate the influence of air mass origin, daily groundlevel 5-day back trajectories were analysed. Because PAN concentrations showed no systematic trends as a function of latitude or altitude of the initial points of the trajectories, an identification of the source region of air masses with enhanced PAN concentrations remains impossible.

Year-round measurements of PAN concentrations in higher northern latitudes have shown that PAN follows a distinct seasonal variation (Bottenheim et al., 1994). During summertime PAN concentrations decrease due to increased photochemical destruction of its organic precursors. If the same annual variation of PAN occurs in the high southern latitudes it may be concluded that the PAN concentrations obtained during PEAN'99 were probably lower than the annual mean because the campaign was performed in late austral summer.

\subsection{PAN lifetimes}

For further investigations of the PAN concentrations, we calculated PAN lifetimes which are mainly dependent on the ambient air temperature. The campaign may be divided due to the meteorological conditions into consecutive periods of several days with either low wind speeds and temperatures or high wind speeds and temperatures accompanied with strongly drifting snow. The different periods are indicated in Fig. 2. The highest PAN concentrations were observed during the two periods with low wind speed and temperature. Although the mean mixing ratio for these periods was slightly higher (17 pptv) compared to the rest of the campaign (11 pptv), the difference in the PAN mixing ratios was not statistically significant.

Reactions (R1)-(R4) demonstrate that PAN lifetimes are influenced by temperature as well as by concentration ratios of $\mathrm{NO}_{2}$ to $\mathrm{NO}$ and $\mathrm{NO}_{2}$ to organic peroxy radicals $\mathrm{RO}_{2}$ (Seinfeld and Pandis, 1998).

$$
\begin{aligned}
& \mathrm{CH}_{3} \mathrm{C}(\mathrm{O}) \mathrm{OONO}_{2} \rightleftharpoons \mathrm{CH}_{3} \mathrm{C}(\mathrm{O}) \mathrm{OO}+\mathrm{NO}_{2}, \\
& \mathrm{CH}_{3} \mathrm{C}(\mathrm{O}) \mathrm{OO}+\mathrm{NO} \rightarrow \mathrm{CH}_{3}+\mathrm{CO}_{2}+\mathrm{NO}_{2}, \\
& \mathrm{CH}_{3} \mathrm{C}(\mathrm{O}) \mathrm{OO}+\mathrm{RO}_{2} \rightarrow \Pi .
\end{aligned}
$$

We applied Eqs. (1) and (2) to calculate PAN decay rates during the campaign using reaction rate constants reported by Bridier et al. (1991) and DeMore et al. (1997) and measured $\mathrm{NO}_{2}$ to $\mathrm{NO}$ ratios (Fig. 3).

$$
\begin{aligned}
& -\frac{\mathrm{d}[\mathrm{PAN}]}{\mathrm{d} t}=k_{1}[\mathrm{PAN}], \\
& -\frac{\mathrm{d}[\mathrm{PAN}]}{\mathrm{d} t}=k_{1}[\mathrm{PAN}]\left(1-\frac{k_{2}}{k_{2}+k_{3}[\mathrm{NO}] /\left[\mathrm{NO}_{2}\right]}\right) .
\end{aligned}
$$

While the upper limit of the decay rates is defined by Eq. (1), the rates obtained with Eq. (2) represent only the lower limits. Additional reactions of acetyl peroxy radicals with organic peroxy radicals (R4) or aerosols can further increase the PAN decay rate. However, the actual decay rate is restricted to the range of the calculated upper and lower limits. Obviously, the decay rates can be lowered by more than one order of magnitude at high ratios of $\left[\mathrm{NO}_{2}\right] /[\mathrm{NO}]$. Nevertheless, Fig. 3 shows that most of the calculated lower limits of the decay rate are similar to the upper limits defined by reaction (R1). While all calculated rates comprise a range of $<10^{-3}-0.4 \mathrm{pptv} \mathrm{h}^{-1}$, most of them $(>75 \%)$ were in the much narrower range of $10^{-2}-10^{-1} \mathrm{pptv} \mathrm{h}^{-1}$. Assuming a mean rate of 


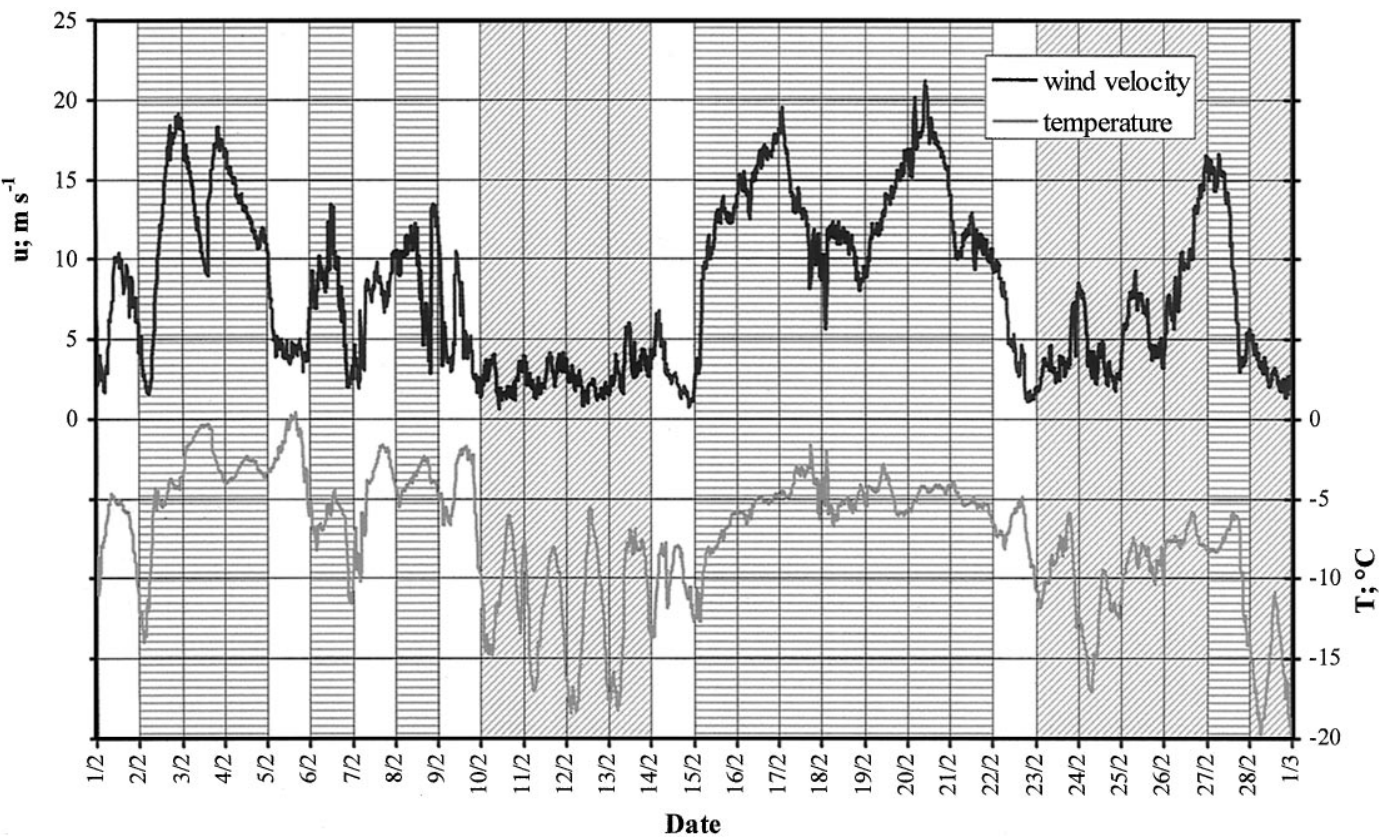

Fig. 2. Time series of air temperature and wind velocity measured at Neumayer station during February 1999. Periods with strong snow drift are indicated by vertically hatched areas; periods with low wind speeds and temperatures by diagonally hatched areas.

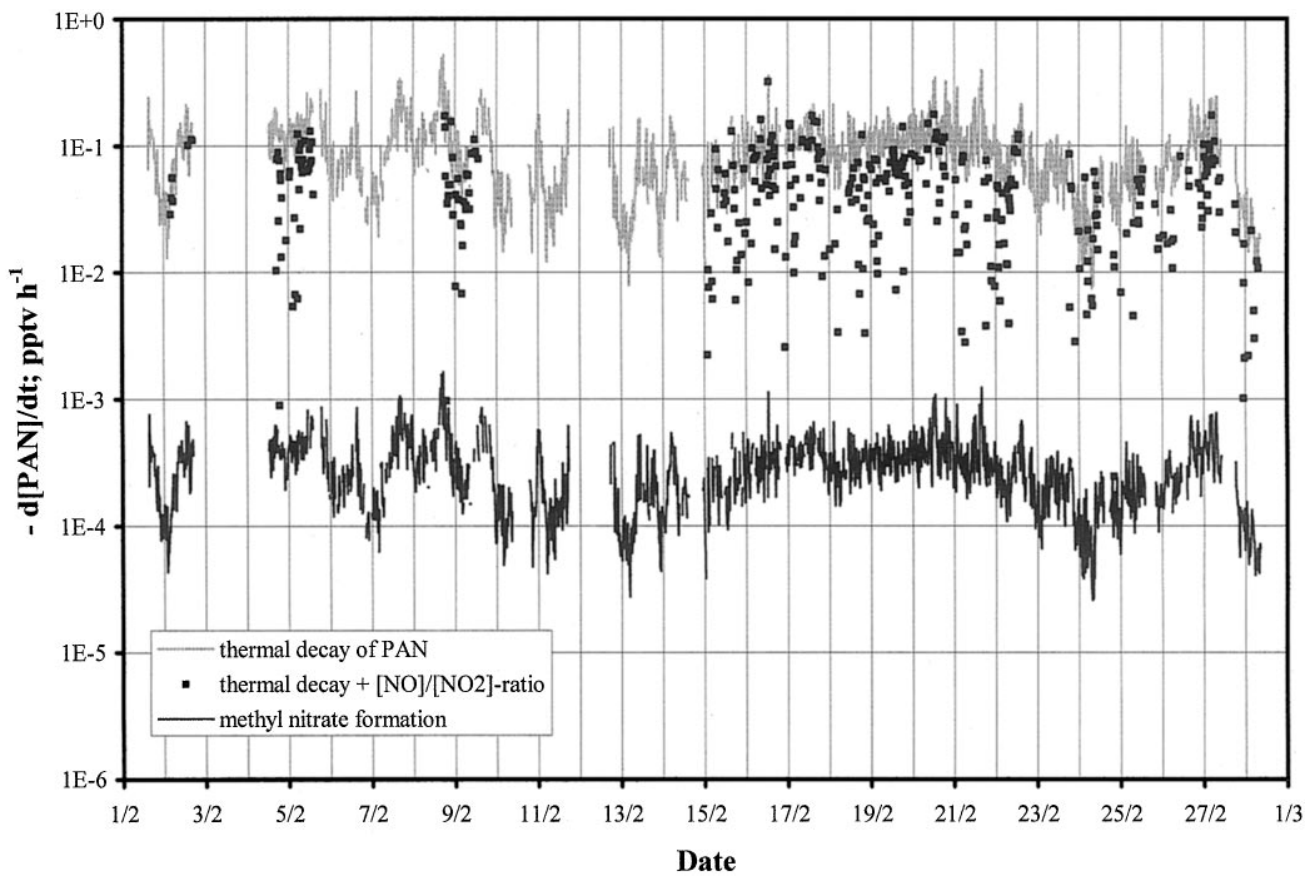

Fig. 3. Calculated PAN decay rates during PEAN'99. The grey line corresponds to the thermal decay calculated using Eq. (1); the squares include thermal decay and $[\mathrm{NO}] /\left[\mathrm{NO}_{2}\right]$ ratio following Eq. (2); the black line corresponds to simulated methyl formation rates using reaction rate constant given by Senum et al. (1986). 
$5 \times 10^{-2}$ pptv h $^{-1}$ during the day with a sun shine duration of $12 \mathrm{~h}$, a total decay of $0.6 \mathrm{pptv} \mathrm{d}^{-1}$ may be estimated. This decay is equivalent to the concurrent $\mathrm{NO}_{x}$ production because one additional $\mathrm{NO}_{2}$ molecule is formed during the decay of a PAN molecule.

Despite of the long lifetime, the observed PAN mixing ratios exhibit a high variability. Jobson et al. (1999) reported variability-lifetime relationships for different regions in the troposphere and the stratosphere. They found a general relationship of the form

$S_{\ln X}=A \tau^{b}$

with $s_{\ln X}$ the standard deviation of the $\ln$ of the mixing ratios, $\tau$ the lifetime in $d$, and $A$ and $b$ adjustable parameters. For the PEAN'99 campaign we calculated a standard deviation of the PAN mixing ratio of $s_{\ln [\mathrm{PAN}]}=0.44$ and a mean PAN lifetime of $\tau=30.3 \mathrm{~d}$ taking into account the thermal decomposition and the $\mathrm{NO}$ to $\mathrm{NO}_{2}$ ratio. Jobson et al. (1999) reported a maximum range of 1.6-4.3 for parameter A for organic compounds observed in remote marine and arctic regions. With these upper and lower limits of $\mathrm{A}$ and the measured quantities $s_{\ln [\mathrm{PAN}]}$ and $\tau_{\mathrm{PAN}}$, we can calculate a range of -0.38 to -0.67 for the exponent $b$ for our study using Eq. (3).

Jobson et al. (1999) demonstrated that the exponent $b$ is correlated to the distance from source regions. The lower limit of $b=-1$ can be expected for a region isolated from any sources like Antarctica, because for this condition the variability results solely from the amount of photochemical degradation in different air masses. In contrast, the estimated range for $b$ in this study is considerably higher. Given that the measured variability $s_{\ln [\mathrm{PAN}]}$ is correct, the deviation of the estimated range for $b$ to the expected value of -1 can be explained by a shorter PAN lifetime. The actual PAN lifetime is probably less than the calculated lifetime of $30.3 \mathrm{~d}$ due to further reactions of the acetyl peroxy radicals, reactions of PAN with $\mathrm{OH}$ and/or PAN photolysis; however, at the earth surface the last two reactions can be neglected (Roberts, 1990). Instead, PAN deposition to the snow surface may be responsible for a significant decrease of the PAN lifetime in the PBL of Antarctica. With the observed PAN variability and the expected parameter $b=-1$, we obtain lifetimes in the range of 4-10 d using values of 1.6 and 4.3 for parameter $A$ in Eq. (3). A PAN flux of $2-5 \times 10^{10}$ molecules $\mathrm{m}^{-2} \mathrm{~s}^{-1}$ is already sufficient to deplete a $100 \mathrm{~m}$ thick PBL with a homogeneous PAN mixing ratio of 13 pptv within $4-10 \mathrm{~d}$.

The role of PAN acting as a precursor of $\mathrm{NO}_{x}$ has been investigated for the remote troposphere over the tropical South Atlantic and South Pacific (Heikes et al., 1996; Jacob et al., 1996; Schultz et al., 1999). Although PAN mixing ratios were less than 5 pptv in the marine boundary layers, PAN decomposition accounted for $\mathrm{NO}_{x}$ production rates of a few $\mathrm{pptv} \mathrm{h}^{-1}$ which was mainly due to the much higher temperatures in tropical latitudes. Further modelling studies have shown that these $\mathrm{NO}_{x}$ production rates were sufficient to establish $\mathrm{NO}_{x}$ mixing ratios of less than 10 pptv. Observations made in the middle to lower summertime troposphere over Alaska have indicated that under certain conditions the thermal decomposition of PAN alone could account for the concurrent measured $\mathrm{NO}_{x}$ abundance in the lower 6-km tropospheric column (Singh et al., 1992b), whereas in other cases the middle tropospheric (4-6 km) abundance of $\mathrm{NO}_{x}$ may have been controlled by the degradation of other organic nitrates due to photolysis or reaction with OH (Jacob et al., 1992).

Assuming the same mechanisms for the oxidation of $\mathrm{NO}_{x}$ in the lower troposphere at higher northern and southern latitudes, the $\mathrm{NO}_{x}$ decay rates can be estimated. Jacob et al. (1992) demonstrated that the main chemical sink is the reaction of $\mathrm{NO}_{2}$ with $\mathrm{OH}$ forming nitric acid $\mathrm{HNO}_{3}$. For this reaction they found averaged rates of 2 pptv $\mathrm{h}^{-1}$ in the lower $1 \mathrm{~km}$ of the troposphere over the North American continent. This rate was calculated for a mean $\mathrm{NO}_{x}$ concentration of $25 \mathrm{pptv}$ (Sandholm et al., 1992) which was a factor of 5.7 higher than the $\mathrm{NO}_{x}$ mixing ratios of this study. Therefore, it can be expected that the $\mathrm{NO}_{x}$ decay rates were also lower by the same factor giving a value of approximately $0.35 \mathrm{pptv} \mathrm{h}^{-1}$. This rate is still higher than the maximum $\mathrm{NO}_{x}$ formation rate due to thermal PAN decay (see. Fig. 3), thus indicating that PAN decomposition was probably not sufficient to maintain observed $\mathrm{NO}_{x}$ mixing ratios (Fig. 4). However, global modelling studies (e.g. Wang et al., 1998) show that surface $\mathrm{OH}$ concentrations in higher southern latitudes in January can be lower by a factor of 2-4 compared to northern mid-latitudes where PAN decay rates are comparable to $\mathrm{NO}_{x}$ destruction rates (Jacob et al., 1992). Taking into account these uncertainties in the $\mathrm{OH}$ mixing ratios during the campaign, the calculation of the $\mathrm{NO}_{x}$ destruction of $0.7 \mathrm{pptv}$ $\mathrm{h}^{-1}$ is only a rough estimate. A modelling study using the measured mixing ratios as input parameters is necessary for a more precise comparison.

The appearance of methyl nitrate in the atmosphere has been at least partly attributed to a uni-molecular cyclic decomposition of PAN (Stephens, 1969; Senum et al, 1986; Roberts, 1990) due to the reaction

$$
\mathrm{CH}_{3} \mathrm{C}(\mathrm{O}) \mathrm{OONO}_{2} \rightarrow \mathrm{CH}_{3} \mathrm{ONO}_{2}+\mathrm{CO}_{2} \text {. }
$$

Although this pathway has been proven to be much less important than it once was thought to be, and may not occur at all (Orlando et al., 1992; Roumelis and Glavas, 1992), we used the rate coefficient reported by Senum et al. (1986) to derive an upper limit for the methyl nitrate formation. The calculated PAN decay rates equivalent to the methyl nitrate formation rates are shown in Fig. 3. Even these upper limits were always less than $10^{-3} \mathrm{pptv} \mathrm{h}^{-1}$. During a former summer campaign at Neumayer, methyl nitrate mixing ratios in the range 


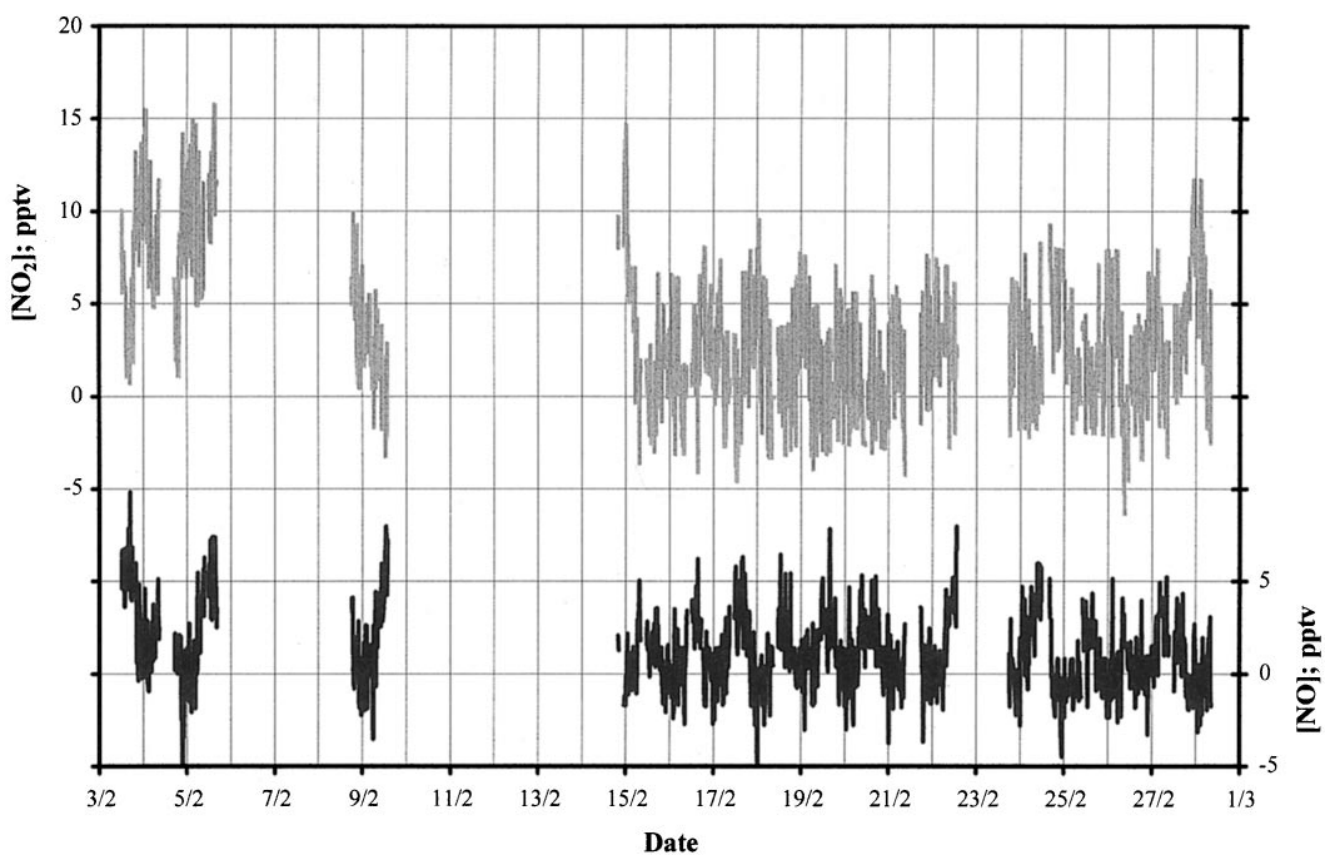

Fig. 4. Time series of $\mathrm{NO}$ and $\mathrm{NO}_{2}$ measured at Neumayer station during PEAN'99.

of 27-46 pptv with a mean concentration of $37 \pm 7 \mathrm{pptv}$ have been observed (Jones et al., 1999). These results have been confirmed by alkyl nitrate measurements during this study (Jones et al., 2000b). It can be concluded that the homogeneous formation of methyl nitrate in the gas phase due to reaction (R5) was negligible and other sources like long-range transport or oceanic emissions must be invoked to explain the local budget of methyl nitrate.

\section{3. $N O_{y}$ budget}

Another focus of the campaign was to compare PAN concentrations with concentrations of other reactive nitrogen compounds. Therefore, we present additional measurements of $\mathrm{HNO}_{3}$ and $\mathrm{p}-\mathrm{NO}_{3}^{-}$. The observed inorganic nitrate concentrations are shown in Fig. 5. The values correspond to mean concentrations for the sampling periods of individual filters represented by horizontal bars. Mixing ratios of $\mathrm{HNO}_{3}$ and $\mathrm{p}-\mathrm{NO}_{3}^{-}$were in the range of 1.8-8 pptv and 1.3-11.7 pptv, respectively. Averaged mixing ratios of 4 pptv for both compounds were calculated (see Table 1).

The sum of reactive nitrogen compounds $\left(\mathrm{NO}_{y}\right)$ is thought to consist primarily of the sum of $\mathrm{NO}, \mathrm{NO}_{2}$, $\mathrm{HONO}, \mathrm{HNO}_{3}, \mathrm{HO}_{2} \mathrm{NO}_{2}, \mathrm{NO}_{3}, 2 \mathrm{~N}_{2} \mathrm{O}_{5}, \mathrm{PAN}$ and p- $\mathrm{NO}_{3}^{-}$(e.g. Sandholm et al., 1994). Other organic nitrates may contribute as well. The distribution of the individual nitrogen-containing species has been subject to several intensive field studies (Bradshaw et al., 1998). The results have shown that in large parts of the troposphere $\mathrm{NO}_{y}$ is dominated by $\mathrm{NO}_{x}, \mathrm{PAN}$ and inorganic nitrate, however, their contributions vary systematically. The $\mathrm{NO}_{x}$ contribution is normally highest in regions with strong anthropogenic sources, PAN dominates in rural areas in temperate latitudes with active photochemistry including oxidation of organic compounds or at low temperatures at high northern latitudes and higher altitudes of the northern hemisphere, while the contribution of inorganic nitrate is highest in other remote parts of the troposphere. These variations can be mainly explained by the sources and sinks of the individual species, because the tropospheric lifetimes of PAN and inorganic nitrate are considerably longer compared to other nitrogen containing species like $\mathrm{NO}_{x}, \mathrm{NO}_{3}, \mathrm{~N}_{2} \mathrm{O}_{5}$ or HONO.

Similarly, the mean concentrations of PAN and $\mathrm{NO}_{x}$ observed in this study differ by a factor of 3 . This ratio, however, remains highly uncertain taking into account the errors for both values in the low pptv range. Nevertheless, PAN concentrations were higher than $\mathrm{NO}_{x}$ concentrations most of the time of the campaign (Fig. 6). The mean ratio is in reasonable agreement with the PAN to $\mathrm{NO}_{x}$ ratio of 10 pptv to 6 pptv estimated for the campaign in 1997 at Neumayer (Jones et al., 1999). Nevertheless, this ratio is low compared to most of the values reported for Arctic regions. At higher northern latitudes PAN contributed up to $90 \%$ of measured $\mathrm{NO}_{y}$ (e.g. Barrie et al., 1989; Solberg et al., 1997) inferring high PAN to $\mathrm{NO}_{x}$ 


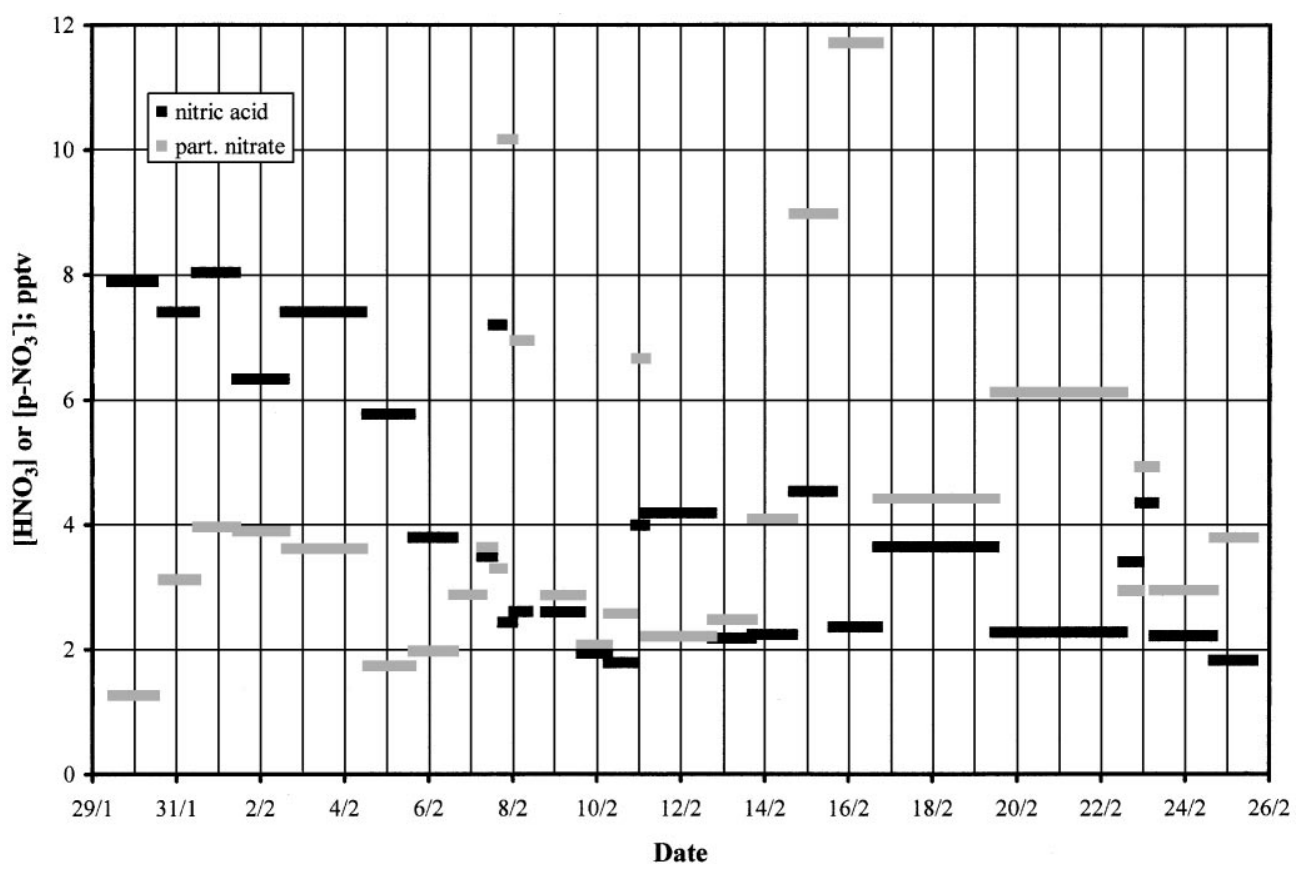

Fig. 5. Time series of $\mathrm{HNO}_{3}$ and $\mathrm{p}-\mathrm{NO}_{3}^{-}$measured at Neumayer station during PEAN'99.

Table 1

Summary of mixing ratios (pptv) of individual odd-nitrogen species measured at Neumayer station, during PEAN'99

\begin{tabular}{lcccccc}
\hline $\mathrm{NO}_{y}$ (i) & $N$ & Minimum & Maximum & Mean & S.D. & Median \\
\hline $\mathrm{PAN}$ & 1544 & $<5$ & 47.9 & $13.1^{\mathrm{a}}$ & 7.3 & 11.5 \\
$\mathrm{NO}$ & 977 & $<1$ & 9.8 & 1.2 & 2.2 & 1 \\
$\mathrm{NO}_{2}$ & 977 & $<1$ & 15.7 & 3.2 & 3.7 & 3.2 \\
$\mathrm{NO}_{x}{ }^{\mathrm{b}}$ & 977 & $<2$ & 20.2 & 4.0 & 2.0 & 3.8 \\
$\mathrm{HNO}_{3}$ & 1867 & 1.8 & 11.7 & 4.2 & 2.4 & 3.6 \\
$\mathrm{p}^{-\mathrm{NO}_{3}^{-}}$ & 1867 & 1.3 & 8.0 & & 3.8 \\
\hline
\end{tabular}

${ }^{a}$ Mean value calculated using $2.5 \mathrm{pptv}$ if $[\mathrm{PAN}]<5 \mathrm{pptv}$.

${ }^{\mathrm{b}} \mathrm{NO}_{x}=\mathrm{NO}+\mathrm{NO}_{2}$.

ratios. However, these high ratios were normally found during early springtime. Due to the negligible photochemical oxidation during the Arctic polar night, organic precursors of PAN are enriched in the Arctic troposphere leading to a significant PAN production of 1-2 pptv $\mathrm{h}^{-1}$ in large Arctic areas with increased radiation after polar sunrise (Solberg et al., 1997; Jacobi et al., 1999). According to these processes, PAN mixing ratios in the Arctic exhibit a strong seasonality with highest values during spring and decreasing concentrations during summer (Bottenheim et al., 1994) corresponding to high PAN to $\mathrm{NO}_{x}$ ratios in spring and lower ratios in summer. Thus, mean PAN and $\mathrm{NO}_{x}$ concentrations observed in the lowest $3000 \mathrm{~m}$ of the troposphere over the North
American high latitudes in July/August 1988 were equal (Bradshaw et al., 1998), probably also as a result of continental $\mathrm{NO}_{x}$ emissions. Compared to these results, the PAN to $\mathrm{NO}_{x}$ ratio in this study was only slightly higher and, therefore, lower than expected taking into account the long distance to continental $\mathrm{NO}_{x}$ source regions. The lower ratio may be at least partly attributed to a photochemical production of $\mathrm{NO}_{x}$ within the firn layer. Additional investigations during PEAN'99 indicated a possible $\mathrm{NO}_{x}$ source strength of $5 \mathrm{pptv} \mathrm{d}^{-1}$ in the PBL (Jones et al., 2000a) which is significantly higher than homogeneous $\mathrm{NO}_{x}$ production of $0.6 \mathrm{pptv} \mathrm{d}^{-1}$ due to the decay of PAN. Furthermore, the results of this study show that $\mathrm{HNO}_{3}$ and $\mathrm{NO}_{x}$ concentrations were 




Fig. 6. Temporal variation of PAN to $\mathrm{NO}_{x}$ and $\mathrm{HNO}_{3}$ to $\mathrm{NO}_{x}$ ratios at Neumayer station during PEAN'99.

comparable during the campaign. Although this ratio is also highly uncertain due to the uncertainties of the measurements, it is still obvious that observed $\mathrm{HNO}_{3}$ to $\mathrm{NO}_{x}$ ratios were considerably lower than expected from results of modelling studies for remote tropospheric air masses (Chatfield, 1994). Simulated $\left[\mathrm{HNO}_{3}\right] /\left[\mathrm{NO}_{x}\right]$ ratios are in the range of 15-100 compared to measured ratios rarely exceeding a value of 10 (Fig. 6). A lower ratio compared to simulated values can be due to several processes not included in the model like an additional source of $\mathrm{NO}_{x}$, an additional sink of inorganic nitrate or a conversion of $\mathrm{HNO}_{3}$ to $\mathrm{NO}_{x}$. Chatfield (1994) and Fan et al. (1994) argued that a conversion of $\mathrm{HNO}_{3}$ in acid aerosols in the presence of formaldehyde could occur in the upper troposphere. However, the low $\left[\mathrm{HNO}_{3}\right] /\left[\mathrm{NO}_{x}\right]$ ratios are also consistent with a significant emission of $\mathrm{NO}_{x}$ from the firn layer.

\subsection{PAN fluxes}

Reactive nitrogen compounds can possibly play an important role in air-snow exchange influencing nitrate concentrations in the ice. The knowledge of these processes is crucial for a correct interpretation of nitrate signals in ice cores. Details of the mechanism of the deposition and evaporation of nitrogen containing compounds are still unknown. Singh et al. (1992a) as well as Dibb et al. (1998) speculated that the transfer of PAN can be of great importance for the deposition of nitrate to glaciers in Greenland. PAN deposition could be of similar importance for the Antarctic ice sheet taking into account that PAN contributes significantly to $\mathrm{NO}_{y}$ in higher southern latitudes.

Therefore, we performed consecutive measurements of PAN mixing ratios at two different heights (2.5 and $0.1 \mathrm{~m}$ above the snow surface). Due to the analysis time of $10 \mathrm{~min}$ for each sample, measurements with a time resolution of $20 \mathrm{~min}$ were obtained at both heights linearly interpolated to calculate mixing ratios and differences in the mixing ratios between both heights every $10 \mathrm{~min}$ (Fig. 7). The differences exhibited a strong variability within the range of $\pm 30 \mathrm{pptv}$. The average of the difference for the whole campaign was $[\mathrm{PAN}](2.5 \mathrm{~m})-$ $[\mathrm{PAN}](0.1 \mathrm{~m})=(0.2 \pm 6.6) \mathrm{pptv}$. It must be noted that due to the precision of the PAN analyser only concentration differences higher than 6 pptv can be resolved.

We further calculated PAN fluxes using the friction velocity $u^{*}$ which was obtained iteratively from Monin-Obukhov surface layer similarity theory with the following integrated equations:

$L=\frac{u^{* 2} T}{\kappa g T^{*}}$,

$\frac{\kappa u_{10 \mathrm{~m}}}{u^{*}}=\ln \left(\frac{z_{10 \mathrm{~m}}}{z_{0}}\right)+\alpha_{\mathrm{M}} \cdot \frac{z_{10 \mathrm{~m}}}{L}$

$\frac{\kappa\left(T_{10 \mathrm{~m}}-T_{2 \mathrm{~m}}\right)}{T^{*}}=\operatorname{Pr} \ln \left(\frac{z_{10 \mathrm{~m}}}{z_{2 \mathrm{~m}}}\right)+\alpha_{\mathrm{T}} z_{10 \mathrm{~m}}-\frac{z_{2 \mathrm{~m}}}{L}$ 


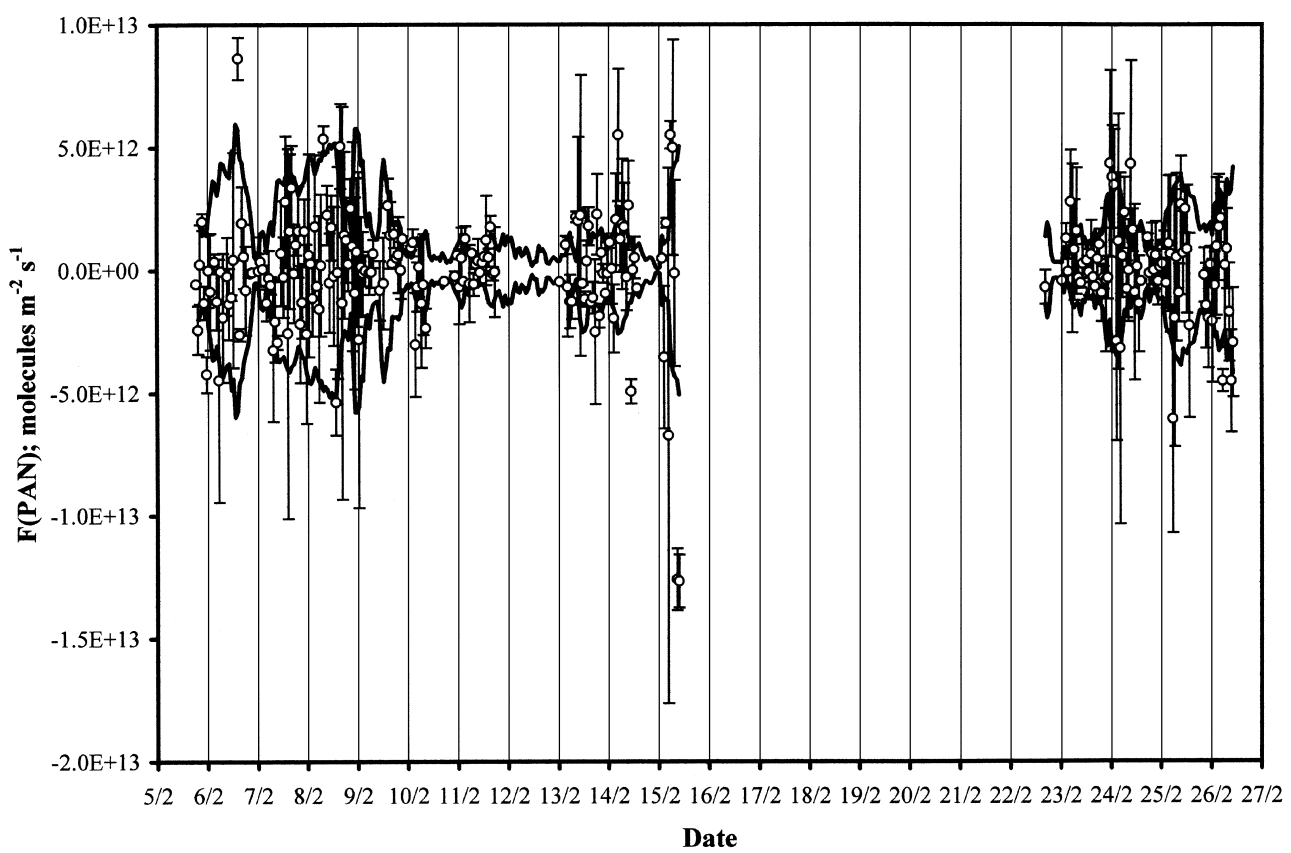

Fig. 7. Calculated 1-h-means of PAN fluxes during PEAN'99. Error bars indicate calculated standard deviations. Positive values correspond to fluxes from the atmosphere to the snow. The lines show the range of fluxes calculated with PAN concentration differences of \pm 6 pptv.

with $L$ being the Monin-Obukhov length; $T$ the mean temperature; $\kappa$ the von Karmans constant $(=0.40)$; $T^{*}$ the scaling temperature; $u$ the wind speed; $z / L$ the stability parameter; $z_{0}$ the aerodynamic roughness length; and $\mathrm{Pr}$ the turbulent Prandtl number $(=0.83)$. Prandtl number, roughness length and the empirical constants $\alpha_{M}$ and $\alpha_{T}$ have been obtained from measurements at Halley station for typical conditions in Antarctica (King and Anderson, 1994). The values of $P r=0.83$, $z_{0}=5.6 \cdot 10^{-5} \mathrm{~m}, \alpha_{\mathrm{M}}=5.7$ and $\alpha_{\mathrm{T}}=4.6$ were also applied for the calculations in this study. Moreover, the Monin-Obukhov length provides a measure of the stability of the surface layer. While the calculation of $u^{*}$ is only applicable at unstable $(L<0)$ and neutral conditions $(L \gg 0)$, values of $u^{*}$ were rejected if $0 \leqslant L \leqslant 4 \mathrm{~m}$. PAN fluxes $\mathrm{F}(\mathrm{PAN})$ were calculated using the following equation:

$F(\mathrm{PAN})=\kappa u^{*} z \frac{[\mathrm{PAN}]_{2.5 \mathrm{~m}}-[\mathrm{PAN}]_{0.1 \mathrm{~m}}}{\Delta z}$

with $z$ being the logarithmic mean of the measuring heights $(=0.5 \mathrm{~m})$ and $\Delta z=2.5-0.1 \mathrm{~m}=2.4 \mathrm{~m}$.

Fig. 7 shows the time series of the averaged 1-h-means of the PAN fluxes. In this case, positive values correspond to fluxes from the atmosphere to the snow and vice versa. Like the concentration differences, a great deal of variability is present in the calculated PAN fluxes and regular variations were not observed. Moreover, almost all of the values are within the range given by the uncertainty of the PAN concentration measurements. Fig. 7 also shows the upper and lower limit of the PAN flux calculated with concentration differences of $[\mathrm{PAN}]_{2.5 \mathrm{~m}}-[\mathrm{PAN}]_{0.1 \mathrm{~m}}= \pm 6 \mathrm{pptv}$. Therefore, no predominant direction of the PAN flux can be given. The results can only be used to estimate limits of the PAN exchange between the troposphere and the underlying snow pack. Except for three outliers on 15 February, all values including the standard deviations are within the range of $\pm 1 \times 10^{13}$ molecules $\mathrm{m}^{-2} \mathrm{~s}^{-1}$. The averaged PAN flux was $-4 \times 10^{10}$ molecules $\mathrm{m}^{-2} \mathrm{~s}^{-1}$ and was more than two orders of magnitude lower than the limits of the observed range. Overall, it appears that if there was any PAN transfer, it was considerably less than the limits of $\pm 1 \times 10^{13}$ molecules $\mathrm{m}^{-2} \mathrm{~s}^{-1}$.

Compared to $\mathrm{NO}_{y}$ fluxes observed at Summit, Greenland (Dibb et al., 1998) the calculated upper limit for PAN fluxes for this study is one order of magnitude lower. Arctic PAN mixing ratios, however, are considerably higher than in Antarctica resulting in higher fluxes between atmosphere and ice under same conditions. On the other hand, the limit is still two orders of magnitude higher than the production rate of $\mathrm{NO}$ and $\mathrm{NO}_{2}$ of $9 \times 10^{10}$ molecules $\mathrm{m}^{-2} \mathrm{~s}^{-1}$ observed in Antarctic snow (Jones et al., 2000). Additionally, a PAN flux of $5 \times 10^{10}$ molecules $\mathrm{m}^{-2} \mathrm{~s}^{-1}$ would lead to a PAN lifetime of less 
than $10 \mathrm{~d}$ due to deposition assuming a $100 \mathrm{~m}$ thick PBL with a homogenous PAN concentration of 13 pptv. This lifetime is much shorter than the value calculated for homogeneous PAN decomposition and is in much better agreement with the variability-lifetime relationship of PAN.

\section{Conclusions}

Although the observed mean PAN concentrations in Antarctica of 13 pptv are in good agreement with the results of global modelling studies, PAN is less important in tropospheric nitrogen chemistry at higher southern latitudes compared to other remote tropospheric regions probably due to its long chemical lifetime even in the Antarctic PBL. Moreover, even though PAN concentrations were sometimes higher than model predictions and were high compared to concentrations of $\mathrm{NO}_{x}$ and inorganic nitrate, homogeneous PAN decomposition is probably not an important source of photochemically active nitrogen compounds. Consequently, further modelling studies are necessary to investigate the role of PAN in tropospheric photochemistry at higher southern latitudes.

Despite the fact that this investigation of PAN fluxes between the atmosphere and snow using the gradient method was limited by the analyser's precision, resulting in a lower limit of verifiable fluxes of $\pm 1 \times 10^{13}$ molecules $\mathrm{m}^{-2} \mathrm{~s}^{-1}$, even significantly lower PAN fluxes can be of importance for the exchange of nitrogen-containing compounds between the atmosphere and the surface snow in Antarctica. The variability of the PAN concentrations which is considerably higher than expected for a long living trace gas in a remote tropospheric region could be explained by the rapid deposition of PAN onto the ice shield. Further measurements with higher resolution and precision are necessary to investigate if PAN fluxes between the atmosphere and snow can be important either for the exchange of nitrogen-containing compounds between the atmosphere and ice or for the PAN destruction and formation in the PBL of Antarctica.

While it can be assumed that long-range transport enhances PAN concentrations considerably above the mean concentration, PAN deposition onto the snow surface may be crucial for the determination of PAN lifetimes in the PBL. Further investigations are necessary to quantify both processes because of their potential to influence the PAN budget in high southern latitudes, thus altering the role of a major contributor of $\mathrm{NO}_{y}$ in a vast area.

\section{Acknowledgements}

The authors thank the scientists and technicians of the Neumayer overwintering crews of the years 1998/1999 and $1999 / 2000$ for their assistance. Moreover, we thank the two anonymous reviewers for their helpful comments on the manuscript. The trajectories have been provided by the German Weather Service (DWD). This research was partially supported by grants from the Deutscher Akademischer Austauschdienst (DAAD) and the British Research Council (BRC). This paper is contribution No. 1690 of the Alfred Wegener Institute for Polar and Marine Research.

\section{References}

Barrie, L.A., den Hartog, G., Bottenheim, J.W., Landsberger, S., 1989. Anthropogenic aerosols and gases in the lower troposphere at Alert Canada in April 1986. Journal of Atmospheric Chemistry 9, 101-127.

Beine, H.J., Jaffe, D.A., Blake, D.R., Atlas, E., Harris, J., 1996. Measurements of PAN, alkyl nitrates, ozone, and hydrocarbons during spring in interior Alaska. Journal of Geophysical Research 101, 12613-12619.

Bottenheim, J.W., Gallant, A.J., 1989. PAN over the Arctic, observations during AGASP-2 in April 1986. Journal of Atmospheric Chemistry 9, 301-316.

Bottenheim, J.W., Gallant, A.J., Brice, K.A., 1986. Measurements of $\mathrm{NO}_{y}$ species and $\mathrm{O}_{3}$ at $82^{\circ} \mathrm{N}$ latitude. Geophysical Research Letters 13, 113-116.

Bottenheim, J.W., Barrie, L.A., Atlas, E., 1993. The partitioning of nitrogen oxides in the lower Arctic troposphere during spring 1988. Journal of Atmospheric Chemistry 17, 15-27.

Bottenheim, J.W., Sirois, A., Brice, K.A., Gallant, A.J., 1994. Five years of continuous observations of PAN and ozone at a rural location in eastern Canada. Journal of Geophysical Research 99, 5333-5352.

Bradshaw, J., Sandholm, S., Talbot, R., 1998. An update on reactive odd-nitrogen measurements made during recent NASA Global Tropospheric Experiment programs. Journal of Geophysical Research 103, 19129-19148.

Bridier, I., Caralp, F., Loirat, H., Lesclaux, R., Veyret, B., Becker, K.H., Reimer, A., Zabel, F., 1991. Kinetic and theoretical studies of the reactions $\mathrm{CH}_{3} \mathrm{C}(\mathrm{O}) \mathrm{O}_{2}+\mathrm{NO}_{2}+\mathrm{M} \leftrightarrow$ $\mathrm{CH}_{3} \mathrm{C}(\mathrm{O}) \mathrm{O}_{2} \mathrm{NO}_{2}+\mathrm{M}$ between 248 and $393 \mathrm{~K}$ and between 30 and 760 Torr. Journal of Physical Chemistry 95, 3594-3600.

Carroll, M.A., Thompson, A.M., 1995. $\mathrm{NO}_{x}$ in the non-urban troposphere. In: Barker, J.R. (Ed.), Progress and Problems in Atmospheric Chemistry. World Scientific, Singapore, pp. 198-255.

Chatfield, R.B., 1994. Anomalous $\mathrm{HNO}_{3} / \mathrm{NO}_{x}$ ratio of remote tropospheric air: conversion of nitric acid to formic acid and $\mathrm{NO}_{x}$ ? Geophysical Research Letters 21, 2705-2707.

DeMore, W.B., Sander, S.P., Golden, D.M., Hampson, R.F., Kurylo, M.J., Howard, C.J., Ravishankara, A.R., Kolb, C.E., Molina, M.J., 1997. Chemical kinetics and photochemical data for use in stratospheric modeling. Evaluation 12, Jet Propulsion Laboratory, Pasadena.

Dibb, J.E., Talbot, R.W., Munger, J.W., Jacob, D.J., Fao, S.-M., 1998. Air-snow exchange of $\mathrm{HNO}_{3}$ and $\mathrm{NO}_{y}$ at summit. Greenland. Journal of Geophysical Research 103, 3475-3486. 
Fan, S.-M., Jacob, D.J., Mauzerall, D.L., Bradshaw, J.D., Sandholm, S.T., Blake, D.R., Singh, H.B., Talbot, R.W., Gregory, G.L., Sachse, G.W., 1994. Origin of tropospheric $\mathrm{NO}_{x}$ over subarctic eastern Canada in summer. Journal of Geophysical Research 99, 16867-16877.

Heikes, B., Lee, M., Jacob, D., Talbot, R., Bradshaw, J., Singh, H., Blake, D., Anderson, B., Fuelberg, H., Thompson, A.M., 1996. Ozone, hydroperoxides, oxides of nitrogen and hydrocarbon budgets in the marine boundary layer over the South Atlantic. Journal of Geophysical Research 101, 24221-24234.

Jacob, D.J., Wofsy, S.C., Bakwin, P.S., Fan, S.-M., Harriss, R.C., Talbot, R.W., Bradshaw, J.D., Sandholm, S.T., Singh, H.B., Browell, E.V., Gregory, G.L., Sachse, G.W., Shipham, M.C., Blake, D.R., Fitzjarrald, D.R., 1992. Summertime photochemistry of the troposphere at high northern latitudes. Journal of Geophysical Research 97, 16421-16431.

Jacob, D.J., Heikes, B.G., Fan, S.-M., Logan, J.A., Mauzerall, D.L., Bradshaw, J.D., Singh, H.B., Gregory, G.L., Talbot, R.W., Blake, D.R., Sachse, G.W., 1996. Origin of ozone and $\mathrm{NO}_{x}$ in the tropical troposphere: a photochemical analysis of aircraft observations over the South Atlantic basin. Journal of Geophysical Research 101, 24235-24250.

Jacobi, H.-W., Schrems, O., 1999. Peroxyacetyl nitrate (PAN) distribution over the South Atlantic Ocean. Physical Chemistry Chemical Physics 1, 5517-5521.

Jacobi, H.-W., Weller, R., Bluszcz, T., Schrems, O., 1999. Latitudinal distribution of peroxyacetyl nitrate (PAN) over the Atlantic Ocean. Journal of Geophysical Research 104, 26901-26912.

Jaffe, D.A., Berntsen, T.K., Isaksen, I.S.A., 1997. A global threedimensional chemical transport model: 2. Nitrogen oxides and nonmethane hydrocarbon results. Journal of Geophysical Research 102, 21281-21296.

Jobson, J.T., McKeen, S.A., Parrish, D.D., Fehsenfeld, F.C., Blake, D.R., Goldstein, A.H., Schauffler, S.M., Elkins, J.W., 1999. Trace gas mixing ratio variability versus lifetime in the troposphere and stratosphere: observations. Journal of Geophysical Research 104, 16113-16901.

Jones, A.E., Weller, R., Minikin, A., Wolff, E.W., Sturges, W.T., McIntyre, H.P., Leonard, S.R., Schrems, O., Baugitte, S., 1999. Oxidized nitrogen chemistry and speciation in the Antarctic troposphere. Journal of Geophysical Research 104, 21355-21366.

Jones, A.E., Weller, R., Wolff, E.W., Jacobi, H.-W., 2000a. Speciation and rate of photochemical $\mathrm{NO}$ and $\mathrm{NO}_{2}$ production in Antarctic snow. Geophysical Research Letters 27, 345-348.

Jones, A.E., McIntyre, H., Sturges, W., Weller, R., Wolff, E.W., Jacobi, H.-W., Mulvaney, R., 2000b. Methyl nitrate at Neumayer, Antarctica - Signal of diurnal variability? in preparation.

King, J.C., Anderson, P.S., 1994. Heat and vapour fluxes and scalar roughness lengths over an Antarctic ice shelf. Boundary Layer Meteorology 69, 101-121.

Kleindienst, T.E., 1994. Recent developments in the chemistry and biology of peroxyacetyl nitrate. Research of Chemical Intermediates 20, 335-384.

Moxim, W.J., Levy II, H., Kasibhatla, P.S., 1996. Simulated global tropospheric PAN: its transport and impact on $\mathrm{NO}_{x}$. Journal of Geophysical Research 101, 12621-12638.
Müller, K.P., Rudolph, J., 1992. Measurements of peroxyacetylnitrate in the marine boundary layer over the Atlantic. Journal of Atmospheric Chemistry 15, 361-367.

Munger, J.W., Jacob, D.J., Fan, S.-M., Colman, A.S., Dibb, J.E., 1999. Concentrations and snow-atmosphere fluxes of reactive nitrogen at Summit. Greenland. Journal of Geophysical Research 104, 13721-13734.

Muthuramu, K., Shepson, P.B., Bottenheim, J.W., Jobson, B.T., Niki, H., Anlauf, K.G., 1994. Relationships between organic nitrates and surface ozone destruction during Polar Sunrise Experiment 1992. Journal of Geophysical Research 99, 25369-25378.

Orlando, J.J., Tyndall, G.S., Calvert, J.G., 1992. Thermal decomposition pathways for peroxyacetyl nitrate (PAN): Implications for atmospheric methyl nitrate levels. Atmospheric Environment 26A, 3111-3118.

Roberts, J.M., 1990. The atmospheric chemistry of organic nitrates. Atmospheric Environment 24A, 243-287.

Roumelis, N., Glavas, S., 1992. Thermal decomposition of peroxyacetyl nitrate in the presence of $\mathrm{O}_{2}, \mathrm{NO}_{2}$ and $\mathrm{NO}$. Monatshefte der Chemie 123, 63-72.

Rudolph, J., Vierkorn-Rudolph, B., Meixner, F.X., 1987. Largescale distribution of peroxyacetylnitrate results from the STRATOZ III flights. Journal of Geophysical Research 92, 6653-6661.

Sandholm, S.T., Bradshaw, J.D., Chen, G., Singh, H.B., Talbot, R.W., Gregory, G.L., Blake, D.R., Sachse, G.W., Browell, E.V., Barrick, J.D.W., Shipham, M.A., Bachmeier, A.S., Owen, D., 1992. Summertime tropospheric observations related to $\mathrm{N}_{x} \mathrm{O}_{y}$ distributions and partitioning over Alaska: Arctic Boundary Layer Expedition 3A. Journal of Geophysical Research 97, 16481-16509.

Sandholm, S., Olsen, J., Bradshaw, J., Talbot, R., Singh, H., Gregory, G., Blake, D., Anderson, B., Sachse, G., Barrick, J., Collins, J., Klemm, K., Lefer, B., Klemm, O., Gorzelska, K., Herlth, D., O'Hara, D., 1994. Summertime partitioning and budget of $\mathrm{NO}_{y}$ compounds in the troposphere over Alaska and Canada: ABLE 3B. Journal of Geophysical Research 99, 1837-1861.

Schrimpf, W., Müller, K.P., Johnen, F.J., Lienaerts, K., Rudolph, J., 1995. An optimized method for airborne peroxyacetyl nitrate (PAN) measurements. Journal of Atmospheric Chemistry $22,303-317$.

Schultz, M.G., Jacob, D.J., Wang, Y., Logan, J.A., Atlas, E.T., Blake, D.R., Blake, N.J., Bradshaw, J.D., Browell, E.V., Fenn, M.A., Flocke, F., Gregory, G.L., Heikes, B.G., Sachse, G.W., Sandholm, S.T., Shetter, R.E., Singh, H.B., Talbot, R.W., 1999. On the origin of tropospheric ozone and $\mathrm{NO}_{x}$ over the tropical South Pacific. Journal of Geophysical Research 104, 5829-5843.

Senum, G.I., Fajer, R., Gaffney, J.S., 1986. Fourier transform infrared spectroscopic study of the thermal stability of peroxyacetyl nitrate. Journal of Physical Chemistry 90, 152-156.

Seinfeld, J.H. and Pandis, S.N., 1998. Atmospheric Chemistry and Physics, 1st Edition. Wiley, New York.

Singh, H.B., Salas, L.J., Viezee, W., 1986. Global distribution of peroxyacetyl nitrate. Nature 321, 588-591.

Singh, H.B., O’Hara, D., Herlth, D., Bradshaw, J.D., Sandholm, S.T., Gregory, G.L., Sachse, G.W., Blake, D.R., Crutzen, P.J., Kanakidou, M.A., 1992a. Atmospheric measurements of peroxyacetyl nitrate and other organic nitrates at high latitudes: 
possible sources and sinks. Journal of Geophysical Research 97, 16511-16522.

Singh, H.B., Herlth, D., O’Hara, D., Zahnle, K., Bradshaw, J.D., Sandholm, S.T., Talbot, R., Crutzen, P.J., Kanakidou, M., 1992b. Relationship of peroxyacetyl nitrate to active and total odd nitrogen at northern high latitudes: influence of reservoir species on $\mathrm{NO}_{x}$ and $\mathrm{O}_{3}$. Journal of Geophysical Research 97, 16523-16530.

Singh, H.B., Herlth, D., O’Hara, D., Zahnle, K., Bradshaw, J.D., Sandholm, S.T., Talbot, R., Gregory, G.L., Sachse, G.W., Blake, D.R., Wofsy, S.C., 1994. Summertime distribution of PAN and other reactive nitrogen species in the northern high-latitude atmosphere of eastern Cananda. Journal of Geophysical Research 99, 1821-1835.

Singh, H.B., Herlth, D., Kolyer, R., Chatfield, R., Viezee, W., Salas, L.J., Chen, Y., Bradshaw, J.D., Sandholm, S.T., Talbot, R., Gregory, G.L., Anderson, B., Sachse, G.W., Browell, E., Bachmeier, A.S., Blake, D.R., Heikes, B., Jacob, D., Fuelberg, H.E., 1996. Impact of biomass burning emissions on the composition of the South Atlantic troposphere: reactive nitrogen and ozone. Journal of Geophysical Research 101, 24203-24219.

Singh, H.B., Viezee, W., Chen, Y., Thakur, A.N., Kondo, Y., Talbot, R.W., Gregory, G.L., Sachse, G.W., Blake, D.R., Bradshaw, J.D., Wang, Y., Jacob, D.J., 1998. Latitudinal distribution of reactive nitrogen in the free troposphere over the Pacific Ocean in late winter/early spring. Journal of Geophysical Research 103, 28237-28246.

Singh, H.B., Viezee, W., Chen, Y., Bradshaw, J., Sandholm, S., Blake, D., Blake, N., Heikes, B., Snow, J., Talbot, R.,
Browell, E., Gregory, G., Sachse, G., Vay, S., 2000. Biomass burning influences on the composition of the remote South Pacific troposphere: analysis based on observations from PEM-Tropics-A. Atmospheric Environment 34, 635-644.

Solberg, S., Krognes, T., Stordal, F., Hov, O., Beine, H.J., Jaffe, D.A., Clemitshaw, K.C., Penkett, S.A., 1997. Reactive nitrogen compounds at Spitsbergen in the Norwegian Arctic. Journal of Atmospheric Chemistry 28, 209-255.

Stephens, E.R., 1969. The formation, reactions, and properties of peroxyacyl nitrates (PANs) in photochemical air pollution. Advances in Environmental Science and Technology 1, 119-146.

Talbot, R.W., Dibb, J.E., Scheuer, E.M., Kondo, Y., Koike, M., Singh, H.B., Salas, L.B., Fukui, Y., Ballenthin, J.O., Meads, R.F., Miller, T.M., Hunton, D.E., Viggiano, A.A., Blake, D.R., Blake, N.J., Atlas, E., Flocke, F., Jacob, D.J., Jaegle, L., 1999. Reactive nitrogen budget during the NASA SONEX mission. Geophysical Research Letters 26, 3057-3060.

Wagenbach, D., Görlach, U., Moser, K., Münnich, K.O., 1988. Coastal Antarctic aerosol: the seasonal pattern of its chemical composition and radionuclide content. Tellus 40B, 426-436.

Wang, Y., Logan, J.A., Jacob, D.J., 1998. Global simulation of tropospheric $\mathrm{O}_{3}-\mathrm{NO}_{x}$-hydrocarbon chemistry, 2. Model evaluation and global ozone budget. Journal of Geophysical Research 103, 10727-10755.

Warneck, P., Zerbach, T., 1992. Synthesis of peroxyacetyl nitrate in air by acetone photolysis. Environmental Science and Technology 26, 74-79. 